DOI: 10.20472/EFC.2017.007.023

\title{
SIMONA VŠETIČKOVÁ
}

University of Economics, Faculty of Economics, Department of Economics, Prague, Czech Republic

\section{THE GOVERNMENT EXPENDITURE STRUCTURE AND ECONOMIC GROWTH}

\begin{abstract}
:
This article examines the effect of the government expenditure structure on the economic growth. The objective is to determine which components of public expenditures are growth enhancing and which growth retarding. The theoretical model is set into the endogenous growth framework and describes the growth mechanism of productive and unproductive government expenditures. The growth impact of public spending composition is analysed for 18 European countries from 1996 to 2012. The empirical part is based on the panel data analysis. The empirical findings suggest that reallocating public resources towards education and health can promote growth. On the contrary higher expenditures on social spending and defence are likely to be growth-retarding.
\end{abstract}

\section{Keywords:}

Government expenditure, Economic growth, Endogenous growth theory

JEL Classification: $\mathrm{E} 62, \mathrm{H} 10, \mathrm{H} 50$ 


\section{Introduction}

The role of the government is to provide goods and services, ensure security, the rule of law, and redistribute income. One of its long-term objective is to promote economic growth of the country. Public spending is one of the government's instruments in pursuit of this aim. The growth promotion via public spending is possible only when the public finances flow into productive areas, which implies that the government expenditure composition is crucial. On that account, thorough analysis of the various spending categories is fundamental to reach optimal allocation of public resources. The analysed topic is relevant, besides other things, for many European countries. They are under pressure to reduce public spending because of unsustainable government debt and must decide where to make necessary financial cuts. The aim of the paper is to analyse the link between government expenditure structure and longrun economic growth.

The growth effects of government expenditure and its main components are explained within the endogenous growth framework. The development of the endogenous growth models is emphasized in historical context of the growth literature, because it created a new view on economic growth and its determinants. The influence of public spending is explained on the grounds of model by Barro (1990). A key aspect is to distinguish between productive and unproductive government outlays. Productive expenditures influence the macroeconomic production function and enhance economic growth. While un-productive expenditures alter only the household's utility.

The theoretical part is completed by summarization of existing empirical evidence in related papers. Special attention is devoted to the discussion about the methodology of modelling of fiscal policy growth effects, which is implemented in the empirical part. It considers the complete nature of fiscal policy and emphasizes how the resulting growth potential of the government spending and its structure depends on the source of funding. The growth impact of public expenditure composition is explored for 18 European countries between 1996 and 2012. The fixed effect panel data approach is used to estimate the regression model with the aim to identify which expenditure components are growth enhancing and which do not promote economic performance of the country. The model is subjected to the robustness tests, and the generalized method of movements is applied to consider the possibility of endogeneity.

\section{Theoretical framework}

The interest in the economic growth and its driving forces is as old as economics as science itself. Understanding of mechanisms behind growth embodies a crucial part of the economic doctrine of classical political economists like Adam Smith, David Ricardo, and Thomas Robert Malthus. However, the topic of growth lost on its priority in times of the marginal revolution (Salvadori, 2003). The economic growth and development became a subject of great importance for the economists after the Second World War. The neoclassical growth models of the 1950s and early 1960s represent first complex theories and building stones of modern growth economics. The Solow-Swan model is a typical example of the neoclassical growth model. The model predicts that the economy converges to the steady state in which the growth rate of 
output (and other variables) is determined by the exogenous rate of technological progress and population growth (Barro, Sala-i-Martin, 2004). Therefore, the scope for the analysis of the connection between fiscal policy and economic growth is considerably limited in the neoclassical growth models. The taxation or the government expenditure influences only the equilibrium factor ratios, not the growth rate (Bleaney, Gemmell, Kneller, 2001).

The endogenous growth theory offers new view on the growth process of the economy and new options how to deal with the drawbacks of neoclassical model (Salvadori, 2003). It brought necessary methodology for the explanation of the effects of other factors (human capital, fiscal policy, environment) on the economic growth. The endogenous theory suggests that the composition of public expenditure is relevant and important issue for the long-run performance of the economy. If the aim is to enhance the long-standing economic growth, public resources should be directed towards more productive items of the budget (Afonso, Furceri, 2008). This question is especially important these days, when many European countries must fight large indebtedness and therefore to tighten the public spending, and at the same time not to harm the long-term growth of the economy. This can be done when the spending cuts are undertaken in the unproductive areas of the government budget. The reallocation of the government expenditure in favour of the growth enhancing components can make the allocation of sources in the economy more efficient and help to remedy the public budget without dramatic reduction in spending or an increase in taxes (Semmler et al., 2007).

Theoretical explanation of the effects of the government expenditure structure on the economic growth provides Barro (1990). The model assumes a closed economy with infinitely-lived households seeking to maximize the life-time overall utility, and production function with constant returns to scale. There are two types of government expenditure: productive and unproductive. Productive expenditures are used as an input to private production and represent potential positive linkage between the government activity and the economic growth. In this concept, production function exhibits constant returns to scale in general but diminishing returns in capital separately. That is, despite the broad notion of capital, there can appear diminishing returns to private inputs (when an increase in the private capital is not accompanied by proportional change in the complementary government inputs).

Such an effect in promotion of private production can exhibit, as an example, the public infrastructure. Private capital such as vehicles or machines can be used more efficiently with the presence of public infrastructure like roads, trails, and bridges (Gemmell, Misch, Moreno-Dodson, 2012). The lack of infrastructure appears to be a major barrier to growth and development (Agénor, 2006).

The model further supposes that the government expenditures are also used to finance some services that enter only the household's utility function (they are not productive) and their growth effect is possibly negative. Higher supply of the government consumption services has no direct effect on private production, but it calls for tax increase. There is lower incentive to save and invest, and the growth of 
the economy tends to slow down. Barro shows that the composition of the government expenditure matters and can be an important determinant of the long- run economic growth.

\section{Existing empirical evidence}

Barro (1990) provides in his paper an empirical analysis of the effects of productive and unproductive government expenditure on long-term growth. His results are in line with the predictions of the theoretical model. Productive spending promotes growth whereas increase in expenditures on non-productive services leads to a lower growth rate. Devarajan, Swaroop, and Zou (1996) analyse panel data for 43 developing countries from 1970 to 1990 and come with the opposite conclusion than Barro. They find that capital, transport and communication, health and education (government expenditure usually perceived as productive) have negative or statistically insignificant impact of growth. Devarajan, Swaroop, and Zou suggest that besides the productivity, initial extent of the spending influences the growth potential of the various categories of expenses. Productive expenditures may not be growth-enhancing if there is an excessive amount of them.

Evans and Karras (1994) conclude that the only activity that has positive effect on growth and fulfils the definition of productive government expenditure is spending on education. This is in accordance with results of Cullison (1993) and Baffes and Shah (1998) that emphasize positive growth effect of expenditure on human capital. Easterly and Rebelo (1993) find that only public investment in transport and communication robustly effects economic growth. Nonetheless, the results of these early studies of endogenous growth (primarily before year 2000) should be treated with caution. There is a number of methodological drawbacks related to these studies (Gemmell, Kneller, Sanz, 2009). Problematic is, for instance, application of crosssection analysis. The traditional OLS analysis is not suitable to determine the direction of causality between fiscal policy variables and growth (Afonso, Jalles, 2013). Crosscountry studies are built on average values of fiscal variables and growth over long periods. These models suffer from endogeneity, simultaneity, errors in the growth variables. The ability to address the impact of demographics and taxes or government spending as ratios and within country variation is also limited.

The application of panel data approach can help to overcome some of the methodological issues and increase information value of the model (Benos, 2009).Development and refinement of new estimation techniques and robustness tests (for endogeneity, heterogeneity in fiscal-growth effects, serial correlation) enable more accurate analysis of the link between the fiscal policy composition and economic growth (Afonso, Jalles, 2013).The majority of papers analysing the connection between fiscal policy (and its components) and economic growth after 2000 use some form of the panel data estimator. Acosta-Ormarchea and Morozumi (2013) find a positive effect of education on economic growth. They conclude that the positive effect of education is present only when an increase in expenditure on education is compensated by a fall in spending on health or social protection. 
Afonso and Furceri (2008) analyse the relationship between government expenditure components, size, and volatility for two subsets of countries, EU and OECD. They find that the total government expenditures seem to impinge negatively on per capita GDP. Countries with a higher share of expenditure tend to grow more slowly. The increase in volatility of expenditures has also negative and statistically significant impact on growth. Subsidies and government consumption belong to components with the negative impact on growth rate in both EU and OECD countries. Benos (2007) discovers a non-linear relationship between expenditure on education and growth. The impact of spending on education is positive and statistically significant and depends on the initial level of education. The higher is the initial level of education, the more the investment in education promotes economic growth. Similar effects were discovered in case of infrastructure outlays and social spending. Also, expenditure on property right protections is reported to influence growth positively.

Gemmel, Kneller, and Sanz (2014) use PMG (pooled mean group) estimator to appraise the growth impacts of public spending composition on economic growth for OECD countries between years 1970 and 2008. Their estimations reveal positive and statistically significant effect of infrastructure and education on GDP per capita in the long run. Positive effect was found in the case of housing and health, and negative for spending on social welfare. Despite many specification issues in both theory and empirical results, after 20 years of development of the endogenous literature, it is now widely believed that the connection between the government spending and economic growth exists in the long run (Gemmell, Misch, Moreno-Dodson, 2012).

\section{Methodology}

Although the purpose of this paper is to examine the effect of public expenditure composition on economic growth, the revenue side of the government budget cannot be ignored. The studies taking into account solely the impact of the government outlays can suffer from systematic biases to the parameter estimates associated with the implicit financing assumption. The influence of the public spending and its structure on the economy is fundamentally dependent on the source of funding (Kneller, Bleaney, Gemmell, 1999).

The government is limited in its decision making by its budget constraint. We already introduced the endogenous growth theory that distinguishes between productive and unproductive expenditure. In a similar manner, we can identify different groups of taxation - distortionary and non-distortionary taxation. Distortionary taxes affect the investment decisions of agents and through the tax burden decrease the long-run growth rate. Non-distortionary taxation does not intervene in investment decisions and hence the effect on the steady-state growth rate is neutral (Gemmell, Kneller, Sanz, 2014). Distortionary taxation encompasses, for instance, income and profit taxes, social security contribution or taxation on property. While taxation on domestic goods and services is usually perceived as non-distortionary (Gemmell, Misch, MorenoDodson, 2012).

Both the public expenditure structure and the composition of taxation determine the long-term growth. The endogenous growth models predict that shifting expenditure 
from unproductive to productive is growth-enhancing. Similarly change in taxation structure towards the non-distortionary taxes has potentially positive effect on growth (Gemmell, Kneller, Sanz, 2014). The combination of different types of taxes and expenses chosen by the government officials determines the possible changes in the growth rates of the economy. Hypotheses about the sign of the effects of the various combinations of government tools are summarized in Table 1.

Table 1 Growth effects of public expenditure, taxes, and budget deficit/surplus

\begin{tabular}{|c|c|c|c|c|}
\hline \multirow{2}{*}{\multicolumn{2}{|c|}{ Source of financing: }} & \multicolumn{2}{|c|}{ Public Spending: } & \multirow{2}{*}{$\begin{array}{l}\text { Budget } \\
\text { Surplus }\end{array}$} \\
\hline & & Productive & Unproductive & \\
\hline \multirow{2}{*}{ Taxes } & Distortionary & $\begin{array}{c}\text { Positive/negative } \\
\text { (at low/high gov. size) }\end{array}$ & Negative & Ambiguous \\
\hline & $\begin{array}{c}\text { Non- } \\
\text { distortionary }\end{array}$ & Positive & Zero & Positive \\
\hline \multicolumn{2}{|c|}{ Budget Deficit } & Ambiguous & Negative & - \\
\hline
\end{tabular}

Source: Gemmell, Kneller, Sanz (2009, pp.19)

From the theoretical perspective is important that the explicit or implicit financing of public spending influences the estimated coefficients. Formally, this approach to fiscal policy analysis can be expressed as follows:

$$
g_{i t}=\alpha+\beta\left(\frac{E}{G D P}\right)_{i t}+\gamma\left(\frac{R}{G D P}\right)_{i t}+\delta\left(\frac{D}{G D P}\right)_{i t}+\sum_{j=1}^{m} \varphi_{j} X_{j t}+u_{i t}
$$

The growth of GDP, $\mathbf{g}_{\mathrm{it}}$, in country $\mathbf{i}$ at time $\mathbf{t}$ is a function of non-fiscal variables, $\mathbf{X}_{\mathbf{j}}$, and fiscal variables - total government expenditures, revenues, and deficit. Equation (1) indicates that the total expenditures, E, must be financed either by revenues, $\mathbf{R}$, and/or via budget deficit/surplus, D. Both revenues and deficits have potential effect on economic growth. Because of the budget constraint the following equality must hold:

$$
D_{i t}=R_{i t}-E_{i t}
$$

In order to avoid perfect collinearity, all variables from the budget constraint cannot be present in the estimated equation. One of them has to be dropped. Let it be $\mathbf{D}_{\text {it }}$ for example. We substitute $\mathbf{D}_{\text {it }}$ from the equation (2) to the equation (1):

$$
g_{i t}=\alpha+(\beta-\delta)\left(\frac{E}{G D P}\right)_{i t}+(\gamma-\delta)\left(\frac{R}{G D P}\right)_{i t}+\sum_{j=1}^{m} \varphi_{j} X_{j t}+u_{i t}
$$

To fulfil the purpose of the paper, we enhance the regression by adding $\mathbf{e}_{\mathbf{i t}}$, which represents the share of one expenditure category to the total expenditures.

$$
g_{i t}=\alpha+(\beta-\delta)\left(\frac{E}{G D P}\right)_{i t}+(\gamma-\delta)\left(\frac{R}{G D P}\right)_{i t}+\psi\left(\frac{e}{E}\right)_{i t}+\sum_{j=1}^{m} \varphi_{j} X_{j t}+u_{i t}
$$

The equation is then estimated repeatedly with a different kind of expenditure to save the degrees of freedom in the regression (Gemmel, Kneller, Sanz, 2014). This specification allows estimating and interpreting the growth effects of fiscal variables more accurately. The estimated parameter on total government expenditure, for 
instance, captures the effect of rise in government spending financed by the budget deficit/surplus. The omitted variable from the regression is the one that is assumed to fund the government action. In other words, 'the correct interpretation of the coefficient on each fiscal category is as the effect of a unit change in the relevant variable offset by a unit change in the omitted category, which is the implicit financing element (Kneller, Bleaney, Gemmell 1999, pp. 174-175). The omitted category has to be chosen very carefully, because the estimated parameters of the regression differ according to the implicit source of financing. The most suitable variable is the one with neutral effect, to which the hypothesis expects the coefficients to be equal to zero (Gemmel, Kneller, Sanz, 2014). In contrast, the coefficient to the partial expenditure category, eit, is not affected by the character of the omitted category. It remains unchanged. It measures the growth effect of a one- unit change of the outlay on a certain expenditure level (expressed as a share to total expenditures), other variables being constant. It implies that the shift of public resources towards one observed spending category is offset (financed) by a decrease in funds flowing to the rest of the categories (Gemmel, Kneller, Sanz, 2009).

\section{Data}

The data were obtained from the Eurostat webpage. The data collection of Eurostat is based on the accounting framework ESA (European system of the national and regional accounts). The former version ESA95 was replaced by new methodological framework ESA2010 in September 2014 (Eurostat, 2014). The first year available (for fiscal variables) after the change of the methodology is 1990 and 2012 is currently the last one. Nevertheless, the time series 1990-2012 is complete only for a small number of countries. The data limitation reduces the sample to 18 European countries. The states included in the dataset are Belgium, the Czech Republic, Denmark, Germany, Ireland, Spain, France, Italy, Latvia, Hungary, the Netherlands, Austria, Portugal, Romania, Finland, Sweden, the United Kingdom and Norway. To keep consistency and a balanced panel, the dataset is restricted to the period of 1996-2012.

The empirical analysis is based on data obtained for the general government. General government sector comprises the central government, local government (city and commune administrations), and social security funds (health insurance fund and unemployment insurance fund) (OECD, 2013). The central government level approach is used in many papers, for instance, Gemmell, Kneller and Sanz (2014), Afonso and Jalles, (2013). However, the data for central government can be distorted when the level of fiscal decentralization varies across different subgroups, which is very likely in the case of public spending components. For example, expenditures on education or health are often more decentralized then spending on defence (Acosta- Ormaechea, Morozumi, 2013). General government represents more homogenous dataset and enables to capture the effect of the whole government on the economic activity (Romero-Ávila, Strauch, 2008).

\subsection{Government expenditure composition}

The functional classification of fiscal variables is used to sort the government expenditure data. The COFOG (Classification of the functions of government) collects 
the data in the framework of ESA2010 and was developed by OECD. It splits spending data into ten functional groups: General public services; Defence; Public order and safety; Economic affairs; Environment protection; Housing; Health; Recreation, Culture and religion; Education, and Social protection (OECD, 2013). The distribution of public resources among the functional components of the government expenditure is presented in figure 1.

Figure 1 Government expenditure by function (1996-2012), average across countries

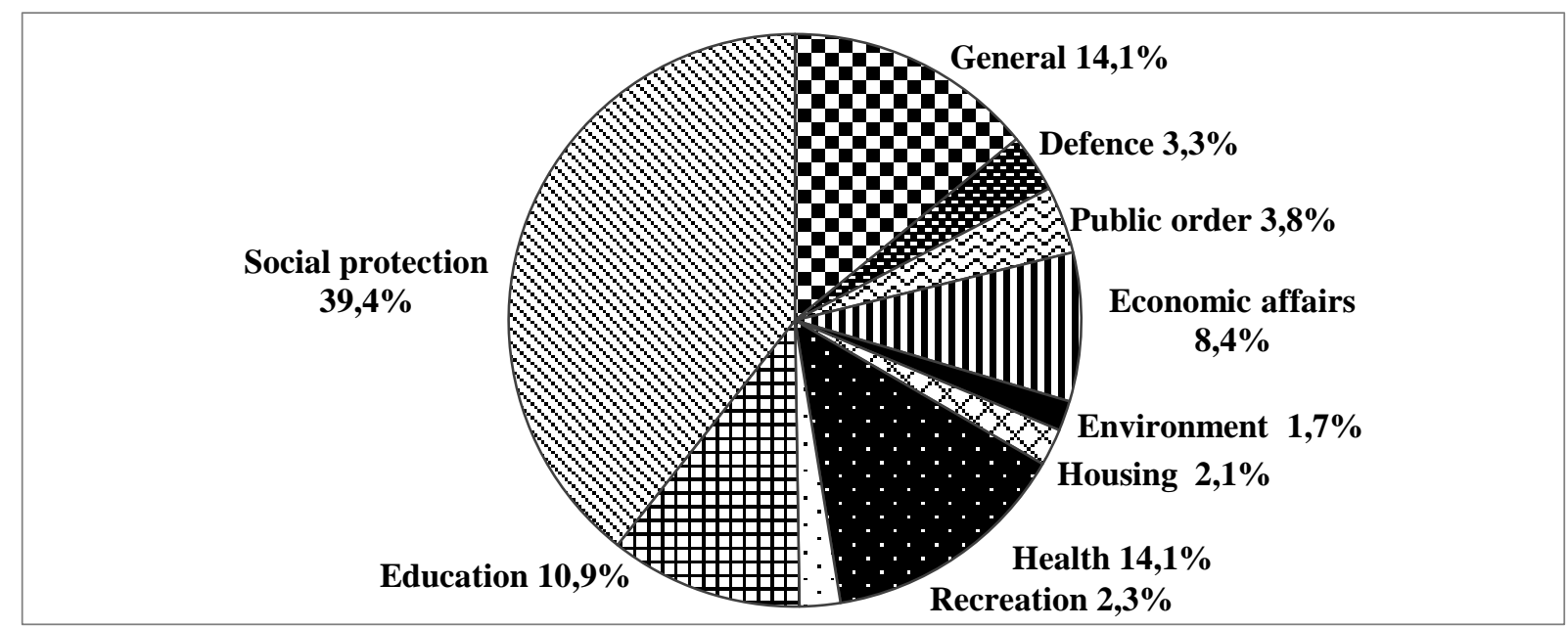

Source: Eurostat, own calculations

\section{Regression analysis}

The regression analysis of the growth effects of the government expenditure composition follows the methodology outlined in chapter3.It starts with the investigation of total government expenditure influence on long-run growth, and illustration of the significance of implicit financing. There are three possible sources of financing identified within the dataset: distortionary taxes, non-distortionary taxes, and government deficit (surplus). Due to the perfect collinearity, all these variables cannot be present in one regression. There are three estimated equations:

\section{Model 1}

$$
\begin{aligned}
g_{i t}=\alpha+ & (\beta-\gamma) \text { Expenditure }_{i t}+(\delta-\gamma) \text { Non_distortionary }_{i t} \\
& +(\theta-\gamma) \text { Distortionary }_{i t}+\sum_{j=1}^{m} \varphi_{j} \text { Control variables }_{j i t}+u_{i t}
\end{aligned}
$$

Model 2

$$
\begin{aligned}
g_{i t}=\alpha+ & (\beta-\delta) \text { Expenditure }_{i t}+(\gamma-\delta) \text { Deficit }_{i t} \\
& +(\theta-\delta) \text { Distortionary }_{i t}+\sum_{j=1}^{m} \varphi_{j} \text { Control variables }_{j i t}+u_{i t}
\end{aligned}
$$

\section{Model 3}

$$
\begin{aligned}
g_{i t}= & \alpha+(\beta-\theta) \text { Expenditure }_{i t}+(\gamma-\theta) \text { Deficit }_{i t} \\
& +(\delta-\theta) \text { Non }_{-} \text {distortionary }_{i t}+\sum_{j=1}^{m} \varphi_{j} \text { Control variables }_{j i t}+u_{i t}
\end{aligned}
$$

To obtain robust results from the regression, the model also incorporates other variables with possible impact on the economic growth (Afonso, Furceri, 2008). The control variables are investment ratio, population growth, GDP per capita, and 
inflation. GDP per capita approximates the initial level of economic development and reflects the effect of convergence between countries on the economic growth according to which countries with lower initial GDP tend to grow faster (Kukk, 2007). Control variables also serve as a tool to capture the potential influence of the business cycle. The government could have the tendency to change its fiscal policy according to the current state of the economy. An increase in expenditures, for instance, often occurs when the economy is at its downfall (Afonso, Jalles, 2013). To take this effect into account the employment rate is added to the regression (the employment responds to the changes in the overall business cycle activity).

Both basic approaches to the panel data analysis, fixed and random effect, were used for estimation of the equations (5), (6), (7). The Hausman's specification test was used to determine which one is more suitable (Baltagi, 2008). The Hausman's test returns $\mathrm{p}$-values lower than 0,05 . We can reject the null hypothesis of no correlation between the explanatory variables and the unit effects. Hence, at the conventional level of significance, we can reject random effect model in favour of the fixed effect model. The variables used in the regression are described in the appendix. The FE estimations are reported in Table 4. It reveals that rise in total public expenditure has negative and statistically significant impact on the economic growth. The direction of this effect is the same regardless of the source of financing. The influence of increased spending is less negative when it is financed via deficit or non-distortionary taxation rather than through distortionary taxation.

Table 4 Regression results, Model 1-3

Dependent variable: Annual GDP growth rate

Estimation technique: fixed effects

\begin{tabular}{|c|c|c|c|}
\hline VARIABLES & Model 1 & Model 2 & Model 3 \\
\hline Total Expenditure & $\begin{array}{l}-0.191^{\star \star \star} \\
(0.0464)\end{array}$ & $\begin{array}{l}-0.361^{\star \star \star} \\
(0.130)\end{array}$ & $\begin{array}{l}-0.181^{*} \\
(0.0987)\end{array}$ \\
\hline Deficit & ---- & $\begin{array}{l}-0.187 \\
(0.131)\end{array}$ & $\begin{array}{l}-0.00836 \\
(0.100)\end{array}$ \\
\hline Non-Distortionary & $\begin{array}{l}0.259^{\star \star} \\
(0.121)\end{array}$ & $\begin{array}{l}0.369^{\star *} \\
(0.161)\end{array}$ & ---- \\
\hline Distortionary & $\begin{array}{l}0.265 \\
(0.177)\end{array}$ & ---- & $\begin{array}{l}0.172 \\
(0.180)\end{array}$ \\
\hline Population growth & $\begin{array}{l}-0.0120^{\star \star \star} \\
(0.00327)\end{array}$ & $\begin{array}{l}-0.0120^{* \star *} \\
(0.00327)\end{array}$ & $\begin{array}{l}-0.0115^{\star \star \star} \\
(0.00331)\end{array}$ \\
\hline Employment growth & $\begin{array}{l}0.793^{\star * \star} \\
(0.0712)\end{array}$ & $\begin{array}{l}0.844^{* \star \star} \\
(0.0700)\end{array}$ & $\begin{array}{l}0.822^{* \star \star} \\
(0.0716)\end{array}$ \\
\hline GDP per capita & $\begin{array}{l}-0.000260 \\
(0.000209)\end{array}$ & $\begin{array}{l}-0.000193 \\
(0.000210)\end{array}$ & $\begin{array}{l}-0.000291 \\
(0.000210)\end{array}$ \\
\hline Inflation & $\begin{array}{l}-0.0528^{\star \star \star} \\
(0.0144)\end{array}$ & $\begin{array}{l}-0.0611^{* * *} \\
(0.0146)\end{array}$ & $\begin{array}{l}-0.0502^{\star \star \star} \\
(0.0145)\end{array}$ \\
\hline Constant & $\begin{array}{l}0.0159 \\
(0.0455) \\
\end{array}$ & $\begin{array}{l}0.0990^{* *} \\
(0.0425)\end{array}$ & $\begin{array}{l}0.0879^{\star} \\
(0.0448) \\
\end{array}$ \\
\hline $\begin{array}{l}\text { Observations } \\
\text { R-squared }\end{array}$ & $\begin{array}{l}306 \\
0.519 \\
\end{array}$ & $\begin{array}{l}306 \\
0.519 \\
\end{array}$ & $\begin{array}{l}306 \\
0.511\end{array}$ \\
\hline
\end{tabular}

The fixed effect technique is used also for the analysis of the effect of the public expenditure structure on the economic growth. The components of public spending are included in the regression as a share to the total government expenditure. 
Coefficients to particular categories are robust to the changes in financing. It is possible to choose just one form of implicit financing. For the next analysis, we assume that the government expenditure is deficit financed and the variable Deficit is omitted from the regression. The equation to be estimated then looks as follows:

Model 4

$$
\begin{array}{r}
g_{i t}=\alpha+(\beta-\gamma) \text { Expenditure }_{i t}+\text { Exxp_Share }_{i t}+(\delta-\gamma) \text { Non_distortionary }_{i t} \\
+(\theta-\gamma) \text { Distortionary } y_{i t}+\sum_{j=1}^{m} \varphi_{j} \text { Control variables }_{j t}+u_{i t}
\end{array}
$$

As in Gemmell, Kneller and Sanz (2009), each category is, in order to save degrees of freedom, included in the regression individually. The results are reported in Tables 5.a and 5.b. The effect of total government expenditure remains negative in all regressions, which is consistent with results in Table 4. The coefficient to education is positive and statistically significant. An increase in expenditure on education that is compensated by a decrease in expenditure on the remaining categories (total expenditure/GDP remains constant) has a positive impact on long run growth. General public services and expenditure on health appear to be also growth-enhancing, and on that account, productive expenditure, although these effects are not statistically significant. Negative growth effect is associated with expenditure on social welfare. The estimation results also indicate that a rise in spending on defence harms the growth of the economy in the long run. Coefficients to public order and safety, recreation, culture and religion, economic affairs, environment protection and housing indicate insignificant impact on growth.

Table 5.a Regression results, Model 4

Dependent variable: Annual GDP growth rate

\begin{tabular}{|c|c|c|c|c|c|}
\hline regression & $(1)$ & (2) & (3) & $(4)$ & (5) \\
\hline Expenditure type & General & Defence & Order & Affairs & Environment \\
\hline Expenditure & 0.0359 & $-0.0465^{\star}$ & -0.0317 & -0.0214 & -0.00606 \\
\hline share & $(0.0784)$ & $(0.0248)$ & $(0.035)$ & $(0.0215)$ & $(0.00644)$ \\
\hline Total Expenditure & $\begin{array}{l}-0.186^{\star \star \star} \\
(0.0471)\end{array}$ & $\begin{array}{c}-0.185^{\star \star \star} \\
(0.0474)\end{array}$ & $\begin{array}{c}-0.184^{\star \star \star} \\
(0.0474)\end{array}$ & $\begin{array}{c}-0.168^{\star \star \star} \\
(0.0505)\end{array}$ & $\begin{array}{c}-0.181^{\star \star \star} \\
(0.0471)\end{array}$ \\
\hline Non-Distortionary & $\begin{array}{l}0.266^{* *} \\
(0.122)\end{array}$ & $\begin{array}{l}0.268^{* *} \\
(0.122) \\
\end{array}$ & $\begin{array}{c}0.260^{\star \star} \\
(0.121)\end{array}$ & $\begin{array}{l}0.241^{*} \\
(0.122)\end{array}$ & $\begin{array}{c}0.256^{\star *} \\
(0.121)\end{array}$ \\
\hline Distortionary & $\begin{array}{l}0.251 \\
(0.179) \\
\end{array}$ & $\begin{array}{l}0.262 \\
(0.177) \\
\end{array}$ & $\begin{array}{l}0.256 \\
(0.177) \\
\end{array}$ & $\begin{array}{l}0.230 \\
(0.179) \\
\end{array}$ & $\begin{array}{l}0.247 \\
(0.177) \\
\end{array}$ \\
\hline $\begin{array}{l}\text { Employment } \\
\text { growth }\end{array}$ & $\begin{array}{c}0.793^{\star \star \star} \\
(0.0713) \\
\end{array}$ & $\begin{array}{c}0.792^{\star * \star} \\
(0.0713) \\
\end{array}$ & $\begin{array}{c}0.790^{\star * \star} \\
(0.0714) \\
\end{array}$ & $\begin{array}{c}0.797^{\star * *} \\
(0.0712) \\
\end{array}$ & $\begin{array}{c}0.785^{\star \star \star} \\
(0.0715) \\
\end{array}$ \\
\hline Population growth & $\begin{array}{c}-1.160^{* \star *} \\
(0.334)\end{array}$ & $\begin{array}{c}-1.149^{* * *} \\
(0.336)\end{array}$ & $\begin{array}{c}-1.143^{* \star *} \\
(0.337)\end{array}$ & $\begin{array}{c}-1.099^{* * *} \\
(0.338)\end{array}$ & $\begin{array}{c}-1.112^{\text {*** }} \\
(0.335)\end{array}$ \\
\hline GDP per capita & $\begin{array}{l}-0.000255 \\
(0.000210) \\
\end{array}$ & $\begin{array}{l}-0.000254 \\
(0.000210) \\
\end{array}$ & $\begin{array}{c}-0.000254 \\
(0.000210) \\
\end{array}$ & $\begin{array}{c}-0.000247 \\
(0.000209) \\
\end{array}$ & $\begin{array}{c}-0.000250 \\
(0.000209) \\
\end{array}$ \\
\hline Inflation & $\begin{array}{c}-0.0532^{* * *} \\
(0.0144)\end{array}$ & $\begin{array}{c}-0.0531^{* * *} \\
(0.0144)\end{array}$ & $\begin{array}{c}-0.0531^{* \star *} \\
(0.0144)\end{array}$ & $\begin{array}{c}-0.0533^{* * *} \\
(0.0144)\end{array}$ & $\begin{array}{c}-0.0530^{\star * \star} \\
(0.0144)\end{array}$ \\
\hline Constant & $\begin{array}{l}0.0154 \\
(0.0456) \\
\end{array}$ & $\begin{array}{l}0.0144 \\
(0.0456) \\
\end{array}$ & $\begin{array}{l}0.0163 \\
(0.0455) \\
\end{array}$ & $\begin{array}{l}0.0185 \\
(0.0455) \\
\end{array}$ & $\begin{array}{l}0.0196 \\
(0.0456) \\
\end{array}$ \\
\hline $\begin{array}{l}\text { Observations } \\
\text { R-squared }\end{array}$ & $\begin{array}{c}306 \\
0.519 \\
\end{array}$ & $\begin{array}{c}306 \\
0.520 \\
\end{array}$ & $\begin{array}{c}306 \\
0.520 \\
\end{array}$ & $\begin{array}{c}306 \\
0.521 \\
\end{array}$ & $\begin{array}{c}306 \\
0.521 \\
\end{array}$ \\
\hline
\end{tabular}

Estimation technique: fixed effects, omitted variable: Deficit

Standard errors in parentheses ${ }^{* * *} p<0.01,{ }^{* *} p<0.05,{ }^{*} p<0.1$ 
Table 5. b Regression results, Model 4

Dependent variable: Annual GDP growth rate

Estimation technique: fixed effects, omitted variable: Deficit

\begin{tabular}{|c|c|c|c|c|c|}
\hline regression & (6) & $(7)$ & $(8)$ & (9) & $(10)$ \\
\hline $\begin{array}{l}\text { Expenditure } \\
\text { type }\end{array}$ & Housing & Health & Education & $\begin{array}{c}\text { Social } \\
\text { protection }\end{array}$ & Recreation \\
\hline $\begin{array}{l}\text { Expenditure } \\
\text { share }\end{array}$ & $\begin{array}{c}-0.0162 \\
(0.0394) \\
\end{array}$ & $\begin{array}{l}\mathbf{0 . 0 1 4 1} \\
(0.0158)\end{array}$ & $\begin{array}{l}\mathbf{0 . 0 8 5 5}^{\star} \\
(0.0475)\end{array}$ & $\begin{array}{c}-\mathbf{0 . 0 8 8 3} 3^{\star \star} \\
(0.0397) \\
\end{array}$ & $\begin{array}{c}-0.0439 \\
(0.0854) \\
\end{array}$ \\
\hline $\begin{array}{l}\text { Total } \\
\text { Expenditure }\end{array}$ & $\begin{array}{c}-0.182^{\star \star \star} \\
(0.0475)\end{array}$ & $\begin{array}{c}-0.179^{\star \star \star} \\
(0.0472)\end{array}$ & $\begin{array}{c}-0.188^{* * *} \\
(0.0464) \\
\end{array}$ & $\begin{array}{c}-0.180^{\star \star \star} \\
(0.0475) \\
\end{array}$ & $\begin{array}{c}-0.187^{\star \star *} \\
(0.0468) \\
\end{array}$ \\
\hline $\begin{array}{l}\text { Non- } \\
\text { Distortionary }\end{array}$ & $\begin{array}{c}0.257^{* *} \\
(0.121) \\
\end{array}$ & $\begin{array}{c}0.250^{* *} \\
(0.121) \\
\end{array}$ & $\begin{array}{l}0.210 \\
(0.128) \\
\end{array}$ & $\begin{array}{c}0.266^{* *} \\
(0.122) \\
\end{array}$ & $\begin{array}{c}0.259^{\star *} \\
(0.121) \\
\end{array}$ \\
\hline Distortionary & $\begin{array}{l}0.245 \\
(0.178) \\
\end{array}$ & $\begin{array}{l}0.245 \\
(0.177) \\
\end{array}$ & $\begin{array}{l}0.230 \\
(0.179) \\
\end{array}$ & $\begin{array}{l}0.256 \\
(0.177) \\
\end{array}$ & $\begin{array}{l}0.253 \\
(0.178) \\
\end{array}$ \\
\hline $\begin{array}{l}\text { Employment } \\
\text { growth }\end{array}$ & $\begin{array}{c}0.791^{\star \star \star} \\
(0.0713)\end{array}$ & $\begin{array}{c}0.787^{\star \star \star} \\
(0.0713)\end{array}$ & $\begin{array}{c}0.785^{\star \star \star} \\
(0.0715)\end{array}$ & $\begin{array}{c}0.789^{\star \star *} \\
(0.0713)\end{array}$ & $\begin{array}{c}0.788^{\star \star \star} \\
(0.0717)\end{array}$ \\
\hline $\begin{array}{l}\text { Population } \\
\text { growth }\end{array}$ & $\begin{array}{c}-1.112^{\star \star \star} \\
(0.341) \\
\end{array}$ & $\begin{array}{c}-1.082^{\star \star \star} \\
(0.340) \\
\end{array}$ & $\begin{array}{c}-1.065^{\star \star \star} \\
(0.346)\end{array}$ & $\begin{array}{c}-1.098^{\star \star *} \\
(0.340)\end{array}$ & $\begin{array}{c}-1.147^{\star \star \star} \\
(0.337) \\
\end{array}$ \\
\hline $\begin{array}{l}\text { GDP per } \\
\text { capita }\end{array}$ & $\begin{array}{c}-0.000251 \\
(0.00021) \\
\end{array}$ & $\begin{array}{c}-0.00025 \\
(0.0002) \\
\end{array}$ & $\begin{array}{c}-0.00019 \\
(0.00028) \\
\end{array}$ & $\begin{array}{c}-0.000253 \\
(0.0002) \\
\end{array}$ & $\begin{array}{c}-0.000253 \\
(0.00021) \\
\end{array}$ \\
\hline Inflation & $\begin{array}{c}-0.0530^{\star \star \star} \\
(0.0144)\end{array}$ & $\begin{array}{c}-0.0527^{\star * \star} \\
(0.0144) \\
\end{array}$ & $\begin{array}{c}-0.0582^{* \star \star} \\
(0.0151) \\
\end{array}$ & $\begin{array}{c}-0.0529^{* * \star} \\
(0.0144) \\
\end{array}$ & $\begin{array}{c}-0.0530^{* \star *} \\
(0.0144) \\
\end{array}$ \\
\hline Constant & $\begin{array}{l}0.0186 \\
(0.0456) \\
\end{array}$ & $\begin{array}{l}0.0197 \\
(0.0456) \\
\end{array}$ & $\begin{array}{l}0.0181 \\
(0.0455) \\
\end{array}$ & $\begin{array}{l}0.0133 \\
(0.0455) \\
\end{array}$ & $\begin{array}{l}0.0178 \\
(0.0456) \\
\end{array}$ \\
\hline $\begin{array}{l}\text { Observations } \\
\text { R-squared }\end{array}$ & $\begin{array}{c}306 \\
0.520 \\
\end{array}$ & $\begin{array}{r}306 \\
0.522 \\
\end{array}$ & $\begin{array}{r}306 \\
0.521 \\
\end{array}$ & $\begin{array}{r}306 \\
0.521 \\
\end{array}$ & $\begin{array}{c}306 \\
0.520 \\
\end{array}$ \\
\hline
\end{tabular}

\subsection{Robustness test}

The regressions from Tables 5.a and 5.b are carried out again in order to verify that the model is robust to changes in assumed implicit financing. This time, the omitted variable is non-distortionary taxation. The results (see Tables 6.a and 6.b) confirm that 4 out of the 10 examined components of public spending have statistically significant impact on growth. Defence and Social protection exhibit negative influence on growth, whereas expenditure on education and health seem to promote growth. Coefficients to the variables reported in Tables 6.a and 6.b are of the same sign and of similar magnitude as the original coefficients in Tables 5.a and 5.b. 
Table 6.a Regression results, Model 4, robustness test

\begin{tabular}{|c|c|c|c|c|c|}
\hline \multicolumn{6}{|c|}{$\begin{array}{c}\text { Dependent variable: Annual GDP growth rate } \\
\text { Estimation technique: fixed effects, omitted variable: Non-Distortionary }\end{array}$} \\
\hline regression & $(1)$ & $(2)$ & (3) & (4) & $(5)$ \\
\hline Expenditure type & General & Defence & Order & Affairs & Environment \\
\hline $\begin{array}{l}\text { Expenditure } \\
\text { share }\end{array}$ & $\begin{array}{l}\mathbf{0 . 0 5 8 3} \\
(0.0832) \\
\end{array}$ & $\begin{array}{c}-0.0461^{*} \\
(0.0221)\end{array}$ & $\begin{array}{c}-0.0378 \\
(0.0399) \\
\end{array}$ & $\begin{array}{c}-0.0285 \\
(0.0245) \\
\end{array}$ & $\begin{array}{c}-0.00683 \\
(0.00984)\end{array}$ \\
\hline Total Expenditure & $\begin{array}{c}-0.365^{\star * \star} \\
(0.130) \\
\end{array}$ & $\begin{array}{c}-0.353^{\star * *} \\
(0.131) \\
\end{array}$ & $\begin{array}{c}-0.354^{* * *} \\
(0.131) \\
\end{array}$ & $\begin{array}{c}-0.349^{\star \star \star} \\
(0.130) \\
\end{array}$ & $\begin{array}{c}-0.352^{\star \star \star} \\
(0.130)\end{array}$ \\
\hline Deficit & $\begin{array}{c}-0.198 \\
(0.132)\end{array}$ & $\begin{array}{l}-0.184 \\
(0.131)\end{array}$ & $\begin{array}{c}-0.188 \\
(0.131)\end{array}$ & $\begin{array}{r}-0.205 \\
(0.131)\end{array}$ & $\begin{array}{l}-0.189 \\
(0.131)\end{array}$ \\
\hline Distortionary & $\begin{array}{l}0.395^{\star *} \\
(0.164)\end{array}$ & $\begin{array}{c}0.377^{\star \star} \\
(0.162)\end{array}$ & $\begin{array}{c}0.373^{\star *} \\
(0.162)\end{array}$ & $\begin{array}{c}0.370^{\star \star} \\
(0.161)\end{array}$ & $\begin{array}{c}0.372^{\star \star} \\
(0.161) \\
\end{array}$ \\
\hline $\begin{array}{l}\text { Employment } \\
\text { growth }\end{array}$ & $\begin{array}{l}0.843^{* * *} \\
(0.0700)\end{array}$ & $\begin{array}{l}0.842^{* * *} \\
(0.0702)\end{array}$ & $\begin{array}{l}0.838^{\star \star *} \\
(0.0703)\end{array}$ & $\begin{array}{c}0.845^{\star \star \star} \\
(0.0698)\end{array}$ & $\begin{array}{c}0.832^{\star \star \star} \\
(0.0705)\end{array}$ \\
\hline Population growth & $\begin{array}{c}-1.136^{\star \star \star} \\
(0.334) \\
\end{array}$ & $\begin{array}{c}-1.150^{* \star *} \\
(0.336)\end{array}$ & $\begin{array}{c}-1.133^{\star * \star} \\
(0.337) \\
\end{array}$ & $\begin{array}{c}-1.064^{\star \star \star} \\
(0.338) \\
\end{array}$ & $\begin{array}{c}-1.101^{\star \star \star} \\
(0.335) \\
\end{array}$ \\
\hline GDP per capita & $\begin{array}{c}-0.000184 \\
(0.000211) \\
\end{array}$ & $\begin{array}{c}-0.000188 \\
(0.000211) \\
\end{array}$ & $\begin{array}{c}-0.000187 \\
(0.000211) \\
\end{array}$ & $\begin{array}{c}-0.000177 \\
(0.000210) \\
\end{array}$ & $\begin{array}{l}-0.000183 \\
(0.000210) \\
\end{array}$ \\
\hline Inflation & $\begin{array}{c}-0.0618^{\star \star \star} \\
(0.0146)\end{array}$ & $\begin{array}{c}-0.0613^{\star \star \star} \\
(0.0146)\end{array}$ & $\begin{array}{c}-0.0614^{\star * \star} \\
(0.0146)\end{array}$ & $\begin{array}{c}-0.0616^{\star \star \star} \\
(0.0146)\end{array}$ & $\begin{array}{c}-0.0611^{\star \star \star} \\
(0.0146)\end{array}$ \\
\hline Constant & $\begin{array}{c}0.0966^{\star *} \\
(0.0426) \\
\end{array}$ & $\begin{array}{c}0.0965^{* *} \\
(0.0427) \\
\end{array}$ & $\begin{array}{c}0.0979^{\star *} \\
(0.0425) \\
\end{array}$ & $\begin{array}{c}0.0979^{* *} \\
(0.0424) \\
\end{array}$ & $\begin{array}{l}0.100^{\star *} \\
(0.0424) \\
\end{array}$ \\
\hline $\begin{array}{l}\text { Observations } \\
\text { R-squared }\end{array}$ & $\begin{array}{c}306 \\
0.520 \\
\end{array}$ & $\begin{array}{c}306 \\
0.519 \\
\end{array}$ & $\begin{array}{c}306 \\
0.520 \\
\end{array}$ & $\begin{array}{c}306 \\
0.522 \\
\end{array}$ & $\begin{array}{c}306 \\
0.521 \\
\end{array}$ \\
\hline
\end{tabular}

\section{Table 6.b Regression results, Model 4, robustness test}

\begin{tabular}{|c|c|c|c|c|c|}
\hline \multicolumn{6}{|c|}{$\begin{array}{c}\text { Dependent variable: Annual GDP growth rate } \\
\text { Estimation technique: fixed effects, omitted variable: Non-Distortionary }\end{array}$} \\
\hline regression & $(6)$ & $(7)$ & $(8)$ & (9) & $(10)$ \\
\hline Expenditure type & Housing & Health & Education & $\begin{array}{c}\text { Social } \\
\text { protection }\end{array}$ & Recreation \\
\hline $\begin{array}{l}\text { Expenditure } \\
\text { share }\end{array}$ & $\begin{array}{c}-0.0199 \\
(0.0274)\end{array}$ & $\begin{array}{l}\mathbf{0 . 0 1 5 6 *} \\
(0.00809)\end{array}$ & $\begin{array}{l}\mathbf{0 . 1 1 8}^{* *} \\
(0.0552)\end{array}$ & $\begin{array}{r}-0.0955^{\star} \\
(0.0499)\end{array}$ & $\begin{array}{c}-0.0565 \\
(0.0604)\end{array}$ \\
\hline Total Expenditure & $\begin{array}{l}-0.352^{\star \star \star} \\
(0.130)\end{array}$ & $\begin{array}{l}-0.349^{\star \star \star} \\
(0.130)\end{array}$ & $\begin{array}{c}-0.385^{\star * *} \\
(0.131)\end{array}$ & $\begin{array}{c}-0.350^{\star \star \star} \\
(0.130)\end{array}$ & $\begin{array}{c}-0.359^{* \star *} \\
(0.130)\end{array}$ \\
\hline Deficit & $\begin{array}{l}-0.189 \\
(0.131)\end{array}$ & $\begin{array}{l}-0.187 \\
(0.131)\end{array}$ & $\begin{array}{l}-0.217 \\
(0.132)\end{array}$ & $\begin{array}{l}-0.188 \\
(0.131) \\
\end{array}$ & $\begin{array}{l}-0.189 \\
(0.131)\end{array}$ \\
\hline Distortionary & $\begin{array}{c}0.373^{\star *} \\
(0.161)\end{array}$ & $\begin{array}{c}0.363^{\star *} \\
(0.161)\end{array}$ & $\begin{array}{c}0.336^{\star *} \\
(0.162) \\
\end{array}$ & $\begin{array}{c}0.380^{* *} \\
(0.162) \\
\end{array}$ & $\begin{array}{c}0.374^{\star *} \\
(0.162) \\
\end{array}$ \\
\hline $\begin{array}{l}\text { Employment } \\
\text { growth }\end{array}$ & $\begin{array}{c}0.838^{\star * *} \\
(0.0701)\end{array}$ & $\begin{array}{c}0.835^{\star \star *} \\
(0.0702) \\
\end{array}$ & $\begin{array}{c}0.830^{\star \star *} \\
(0.0703)\end{array}$ & $\begin{array}{c}0.838^{\star \star \star} \\
(0.0701) \\
\end{array}$ & $\begin{array}{c}0.836^{\star \star \star} \\
(0.0707)\end{array}$ \\
\hline Population growth & $\begin{array}{c}-1.092^{* * *} \\
(0.341)\end{array}$ & $\begin{array}{c}-1.070^{* * *} \\
(0.340)\end{array}$ & $\begin{array}{c}-1.010^{* * *} \\
(0.346)\end{array}$ & $\begin{array}{c}-1.091^{* * *} \\
(0.340)\end{array}$ & $\begin{array}{c}-1.132^{* * *} \\
(0.337)\end{array}$ \\
\hline GDP per capita & $\begin{array}{c}-0.000183 \\
(0.000211)\end{array}$ & $\begin{array}{c}-0.000188 \\
(0.000210)\end{array}$ & $\begin{array}{l}-9.98 \mathrm{e}-05 \\
(0.000217)\end{array}$ & $\begin{array}{c}-0.000186 \\
(0.000210)\end{array}$ & $\begin{array}{c}-0.000185 \\
(0.000211)\end{array}$ \\
\hline Inflation & $\begin{array}{c}-0.0611^{\star * *} \\
(0.0146)\end{array}$ & $\begin{array}{c}-0.0607^{* * *} \\
(0.0146)\end{array}$ & $\begin{array}{c}-0.0687^{\star \star \star} \\
(0.0153)\end{array}$ & $\begin{array}{c}-0.0611^{* * *} \\
(0.0146)\end{array}$ & $\begin{array}{c}-0.0613^{\star \star \star} \\
(0.0146)\end{array}$ \\
\hline Constant & $\begin{array}{c}0.0986^{\star *} \\
(0.0424) \\
\end{array}$ & $\begin{array}{c}0.0993^{\star *} \\
(0.0424)\end{array}$ & $\begin{array}{l}0.0995^{\star *} \\
(0.0423)\end{array}$ & $\begin{array}{c}0.0948^{\star *} \\
(0.0426)\end{array}$ & $\begin{array}{c}0.0992^{\star \star} \\
(0.0425)\end{array}$ \\
\hline $\begin{array}{l}\text { Observations } \\
\text { R-squared }\end{array}$ & $\begin{array}{c}306 \\
0.521\end{array}$ & $\begin{array}{c}306 \\
0.522\end{array}$ & $\begin{array}{c}306 \\
0.523\end{array}$ & $\begin{array}{c}306 \\
0.521\end{array}$ & $\begin{array}{c}306 \\
0.520\end{array}$ \\
\hline
\end{tabular}




\subsection{Testing for serial correlation}

The serial correlation is common issue in fixed and random effects model. Wooldridge's test is used to identify the presence of serial correlation in the model (Drukker, 2003). We now return to the assumption that the source of implicit financing is budget deficit (surplus). Table 7 presents the results of the Wooldridge's test for the regression (1) from Table 5.a. The GDP growth rate is a function of total government expenditure, distortionary and non-distortionary taxes in terms of GDP's share, control variables, and general public service. The null hypothesis of no serial correlation is rejected. In order to save space, the results of the test for the remaining regressions from Tables 5.a and 5.b will not be presented. However, the tests for the rest of the regressions came to the same conclusion. The solution for the possible inefficiency of the regression coefficients due to the serial correlation is discussed in the next section.

\begin{tabular}{|c|c|c|c|c|}
\hline \multicolumn{5}{|c|}{ Wooldridge's test for regression (1) } \\
\hline \multicolumn{3}{|l|}{ Linear regression } & $\begin{array}{l}\text { Number of obs. } \\
F(8,17) \\
\text { Prob > F } \\
\text { R-squared } \\
\text { Root MSE }\end{array}$ & $\begin{array}{l}=288 \\
=218.35 \\
=0.0000 \\
=0.3168 \\
=0.02654\end{array}$ \\
\hline D.Growthrate & Coef. & Robust.std. error & $\mathbf{t}$ & $P>|t|$ \\
\hline General D1. & -0.041 & 0.134 & -0.31 & 0.763 \\
\hline Expenditure D1. & -0.260 & 0.159 & -1.63 & 0.121 \\
\hline Distortionary D1. & -0.224 & 0.219 & -1.02 & 0.323 \\
\hline Nondistortionary D1. & 0.120 & 0.390 & 0.31 & 0.763 \\
\hline Employmentgrowth D1. & 0.631 & 0.177 & 3.56 & 0.002 \\
\hline Populationgrowth D1. & -0.483 & 0.460 & -0.11 & 0.918 \\
\hline GDPpercapita D1. & -0.0001 & 0.0003 & -0.34 & 0.739 \\
\hline Inflation D1. & -0.057 & 0.005 & -10.39 & 0.000 \\
\hline \multicolumn{5}{|c|}{ Wooldridge test for autocorrelation in panel data: } \\
\hline \multicolumn{5}{|c|}{ H0: no first order autocorrelation } \\
\hline \multicolumn{5}{|c|}{$\mathrm{F}(1,17)=9.314$} \\
\hline \multicolumn{5}{|c|}{ Prob $>F=0.0072$} \\
\hline
\end{tabular}

\section{Table 7 Wooldridge's test for regression (1)}

\subsection{Endogeneity}

So far, the government expenditure has been treated as an exogenous variable. Nevertheless, this approach ignores the potential simultaneous relationship between the economic growth and government spending. The size of government expenditure influences growth and simultaneously the public spending reacts to the performance of the economy (Afonso, Furceri, 2008). Government expenditure should be treated as an endogenous variable. Otherwise the estimated coefficients could be biased and inconsistent (Benos, 2009).

The concern about the impact of endogeneity on the validity of regression results relates also to the analysis of growth effects of the expenditure components. For 
example, the unemployment increases in times of economic downturn, which results in rise in unemployment benefits and other social expenses (Gemmell, Kneller, Sanz, 2009).

To address the possible endogeneity and dynamic relationship between government expenditure (and its components) and the economic growth, we apply dynamic panel data estimation approach - generalized method of movements (GMM). GMM is suitable for models with possibly endogenous regressors, serial correlation, and with lack of good instrumental variables. It uses mostly internal instruments: lags of the instrumented variables (Roodman, 2009). The system Blundell and Bond GMM estimator is used in the analysis because it is more suitable for dynamic panel data models, when T is small (which is the case of this study where $T=16$ ) (Baltagi, 2012).

The estimation of the regressions from Tables 5.a and 5.b is repeated with the use of the system GMM (see Tables 8.a and 8.b for results). The effect of total government expenditure remains negative and of similar magnitude although the statistical significance is smaller. The coefficient signs of the examined components of the government expenditure are unchanged. Defence, health, education and social protection keep their statistical significance. In addition, the variable general public services are statistically significant. The results of Arellano-Bond test for autocorrelation are reported in Tables 8.a and 8.b. The diagnostics are satisfactory; the test detects first-order but not second-order serial correlation. The Sargan-Hansen test fails to reject the over-identification conditions.

Table 8.a Regression results, Model 4, GMM estimation

\begin{tabular}{|c|c|c|c|c|c|}
\hline \multicolumn{6}{|c|}{$\begin{array}{l}\text { Dependent variable: Annual GDP growth rate } \\
\text { Estimation technique: GMM, omitted variable: Deficit }\end{array}$} \\
\hline regression & $(1)$ & (2) & (3) & $(4)$ & (5) \\
\hline Expenditure type & General & Defence & Order & Affairs & Environment \\
\hline Expenditure share & $\begin{array}{l}\mathbf{0 . 0 1 2 5} \\
(0.0614)\end{array}$ & $\begin{array}{c}-0.0186^{*} \\
(0.0099)\end{array}$ & $\begin{array}{c}-0.0284 \\
(0.0411)\end{array}$ & $\begin{array}{c}-0.0314 \\
(0.148)\end{array}$ & $\begin{array}{c}-0.00227 \\
(0.00309)\end{array}$ \\
\hline Total Expenditure & $\begin{array}{c}-0.223^{*} \\
(0.112)\end{array}$ & $\begin{array}{c}-0.205^{*} \\
(0.108)\end{array}$ & $\begin{array}{c}-0.220^{*} \\
(0.106)\end{array}$ & $\begin{array}{l}0.208 \\
(0.249)\end{array}$ & $\begin{array}{c}-0.205^{\star} \\
(0.106)\end{array}$ \\
\hline Non- Distortionary & $\begin{array}{l}0.269^{*} \\
(0.129)\end{array}$ & $\begin{array}{l}0.259^{*} \\
(0.139)\end{array}$ & $\begin{array}{l}0.250^{*} \\
(0.130)\end{array}$ & $\begin{array}{r}-0.561 \\
(0.547)\end{array}$ & $\begin{array}{l}0.238 \\
(0.143)\end{array}$ \\
\hline Distortionary & $\begin{array}{r}0.0130 \\
(0.102)\end{array}$ & $\begin{array}{c}0.00181 \\
(0.131)\end{array}$ & $\begin{array}{l}0.0217 \\
(0.101)\end{array}$ & $\begin{array}{l}0.000683 \\
(0.411)\end{array}$ & $\begin{array}{l}0.0226 \\
(0.100)\end{array}$ \\
\hline Employment growth & $\begin{array}{l}0.791^{* * *} \\
(0.190)\end{array}$ & $\begin{array}{c}0.788^{* * *} \\
(0.190)\end{array}$ & $\begin{array}{l}0.787^{* \star *} \\
(0.184)\end{array}$ & $\begin{array}{c}0.974^{* * *} \\
(0.240)\end{array}$ & $\begin{array}{c}0.798^{* * *} \\
(0.179)\end{array}$ \\
\hline Population growth & $\begin{array}{r}-1.187 \\
(0.780)\end{array}$ & $\begin{array}{r}-1.211 \\
(0.761)\end{array}$ & $\begin{array}{c}-1.196 \\
(0.803)\end{array}$ & $\begin{array}{l}0.222 \\
(2.086)\end{array}$ & $\begin{array}{c}-1.303^{*} \\
(0.748)\end{array}$ \\
\hline GDP per capita & $\begin{array}{c}-1.43 \mathrm{e}-05 \\
(7.40 \mathrm{e}-05)\end{array}$ & $\begin{array}{l}-3.43 e-05 \\
(0.000103)\end{array}$ & $\begin{array}{c}-4.46 e-05 \\
(8.08 \mathrm{e}-05)\end{array}$ & $\begin{array}{l}-0.00034 \\
(0.000247)\end{array}$ & $\begin{array}{l}-4.12 \mathrm{e}-05 \\
(7.35 \mathrm{e}-05)\end{array}$ \\
\hline Inflation & $\begin{array}{c}-0.0346^{\star *} \\
(0.0153)\end{array}$ & $\begin{array}{c}-0.0366^{\star *} \\
(0.0147)\end{array}$ & $\begin{array}{c}-0.0380^{\star \star \star} \\
(0.0131)\end{array}$ & $\begin{array}{c}-0.057^{\star \star} \\
(0.0216)\end{array}$ & $\begin{array}{c}-0.0320^{*} \\
(0.0160)\end{array}$ \\
\hline Constant & $\begin{array}{c}0.0884^{\star * \star} \\
(0.0219)\end{array}$ & $\begin{array}{c}0.0830^{\star * \star} \\
(0.0261)\end{array}$ & $\begin{array}{c}0.0888^{\star \star \star} \\
(0.0208)\end{array}$ & $\begin{array}{l}0.0616 \\
(0.115) \\
\end{array}$ & $\begin{array}{c}0.0835^{\star \star \star} \\
(0.0205)\end{array}$ \\
\hline Observations & 306 & 306 & 306 & 306 & 306 \\
\hline $\begin{array}{l}\text { Arellano-Bond test for } \\
A R(1)(p-v a l u e)\end{array}$ & 0.008 & 0.044 & 0.009 & 0.104 & 0.010 \\
\hline $\begin{array}{l}\text { Arellano-Bond test for } \\
\mathrm{AR}(2) \text { ( } \mathrm{p} \text {-value) }\end{array}$ & 0.341 & 0.562 & 0.520 & 0.112 & 0.483 \\
\hline
\end{tabular}


Hansen test of overid. restrictions ( $\mathrm{p}$-value)

$0.570 \quad 0.642 \quad 0.686$

0.697

0.651

Standard errors in parentheses ${ }^{* * *} p<0.01,{ }^{* *} p<0.05,{ }^{*} p<0.1$

Table 8.b Regression results, Model 4, GMM estimation

Dependent variable: Annual GDP growth rate

Estimation technique: GMM, omitted variable: Deficit

\begin{tabular}{|c|c|c|c|c|c|}
\hline regression & (6) & (7) & (8) & (9) & (10) \\
\hline Expenditure type & Housing & Health & Education & Social & Recreation \\
\hline Expenditure share & $\begin{array}{c}-0.00519 \\
(0.033)\end{array}$ & $\begin{array}{c}\mathbf{0 . 0 0 7 0 3 *}^{*} \\
(0.0036)\end{array}$ & $\begin{array}{l}\mathbf{0 . 0 4 1 6 *} \\
(0.0212)\end{array}$ & $\begin{array}{c}-0.0647^{*} \\
(0.0305)\end{array}$ & $\begin{array}{l}-0.0395 \\
(0.0645) \\
\end{array}$ \\
\hline Total Expenditure & $\begin{array}{l}-0.191^{*} \\
(0.106)\end{array}$ & $\begin{array}{c}-0.205^{*} \\
(0.106)\end{array}$ & $\begin{array}{l}-0.193^{*} \\
(0.108)\end{array}$ & $\begin{array}{l}-0.201^{*} \\
(0.107)\end{array}$ & $\begin{array}{l}-0.209^{*} \\
(0.113)\end{array}$ \\
\hline Non- Distortionary & $\begin{array}{l}0.242 \\
(0.146)\end{array}$ & $\begin{array}{l}0.234 \\
(0.143)\end{array}$ & $\begin{array}{l}0.250 \\
(0.148)\end{array}$ & $\begin{array}{l}0.220 \\
(0.145)\end{array}$ & $\begin{array}{l}0.230 \\
(0.139)\end{array}$ \\
\hline Distortionary & $\begin{array}{c}-0.00971 \\
(0.0996)\end{array}$ & $\begin{array}{l}0.0220 \\
(0.0992)\end{array}$ & $\begin{array}{l}-0.0138 \\
(0.102)\end{array}$ & $\begin{array}{c}0.0179 \\
(0.101)\end{array}$ & $\begin{array}{c}0.0224 \\
(0.105) \\
\end{array}$ \\
\hline Employment growth & $\begin{array}{c}0.808^{* \star *} \\
(0.181)\end{array}$ & $\begin{array}{l}0.797^{\star \star \star} \\
(0.180)\end{array}$ & $\begin{array}{l}0.808^{* * *} \\
(0.182)\end{array}$ & $\begin{array}{l}0.802^{\star * \star} \\
(0.180)\end{array}$ & $\begin{array}{c}0.797^{* * \star} \\
(0.197)\end{array}$ \\
\hline Population growth & $\begin{array}{l}-1.249 \\
(0.800)\end{array}$ & $\begin{array}{l}-1.274 \\
(0.744)\end{array}$ & $\begin{array}{l}-1.237 \\
(0.811)\end{array}$ & $\begin{array}{l}-1.248 \\
(0.730)\end{array}$ & $\begin{array}{l}-1.163 \\
(0.789)\end{array}$ \\
\hline GDP per capita & $\begin{array}{l}-4.90 \mathrm{e}-05 \\
(7.07 \mathrm{e}-05)\end{array}$ & $\begin{array}{l}-4.12 \mathrm{e}-05 \\
(7.35 \mathrm{e}-05)\end{array}$ & $\begin{array}{l}-4.37 e-05 \\
(6.96 e-05)\end{array}$ & $\begin{array}{l}-4.15 \mathrm{e}-05 \\
(7.36 \mathrm{e}-05)\end{array}$ & $\begin{array}{l}-2.91 e-05 \\
(7.04 e-05) \\
\end{array}$ \\
\hline Inflation & $\begin{array}{c}-0.0325^{\star *} \\
(0.0151)\end{array}$ & $\begin{array}{c}-0.0324^{*} \\
(0.0158)\end{array}$ & $\begin{array}{l}-0.0319^{*} \\
(0.0156)\end{array}$ & $\begin{array}{c}-0.0328^{\star} \\
(0.0157)\end{array}$ & $\begin{array}{l}-0.0317^{*} \\
(0.0161)\end{array}$ \\
\hline Constant & $\begin{array}{c}0.0837^{\star \star \star} \\
(0.0202)\end{array}$ & $\begin{array}{c}0.0842^{* \star \star} \\
(0.0206)\end{array}$ & $\begin{array}{c}0.0839^{\star \star \star} \\
(0.0214) \\
\end{array}$ & $\begin{array}{l}0.086^{\star \star \star} \\
(0.0213)\end{array}$ & $\begin{array}{c}0.0857^{* * *} \\
(0.0208)\end{array}$ \\
\hline Observations & 306 & 306 & 306 & 306 & 306 \\
\hline $\begin{array}{l}\text { Arellano-Bond test for } \\
\mathrm{AR}(1) \mathrm{p} \text {-value) }\end{array}$ & 0.010 & 0.10 & 0.008 & 0.011 & 0.010 \\
\hline $\begin{array}{l}\text { Arellano-Bond test for } \\
A R(2) \text { (p-value) }\end{array}$ & 0.434 & 0.509 & 0.348 & 0.542 & 0.481 \\
\hline $\begin{array}{l}\text { Hansen test of overid. } \\
\text { restrictions ( } \mathrm{p} \text {-value) }\end{array}$ & 0.610 & 0.650 & 0.608 & 0.650 & 0.646 \\
\hline
\end{tabular}

Standard errors in parentheses ${ }^{* * *} p<0.01,{ }^{* *} p<0.05,{ }^{*} p<0.1$

\section{Conclusion}

In 2012, the total general government expenditure to GDP ratio accounted, on average, for $48 \%$. The scope of the government sector is not negligible in the analysed European countries. It influences the activities in the economy significantly, and so the research of its influence on the economic growth in Europe is justifiable. In this paper, the growth effect of the government outlays composition is examined for 18 European countries in the period 1996-2012. Econometric analysis reveals negative and statistically significant relationship between total government expenditure and the economic growth. Nevertheless, the magnitude of this effect depends on the source of financing. The funding via non-distortionary taxes or budget deficit turns out to be less harmful for growth than the distortionary taxation.

The FE and GMM estimators are used to analyse the impact of functional categories of public expenses on the economic growth. The average country from the dataset spends ( $\%$ total expenditure) $40 \%$ on social welfare, $14 \%$ on health, $11 \%$ on 
education, and $14 \%$ on general public services. The remaining share is allocated among defence, public order, recreation, culture and religion, economic affairs, environment protection, and housing.

The regression results indicate positive influence of expenditure on education and health. By contrast, spending on defence and social protection seem to negatively impinge growth. These results are statistically significant and robust to changes in model specification. Certain positive growth effect can be attributed to general public services. The analysis suggests that education, health, and general public services represent productive expenditure while social protection and defence share unproductive nature. The empirical findings support the endogenous growth theory. Government spending and its composition have significant effect on the economic growth.

\section{Appendix}

\section{Table A. 1 Variable description}

\begin{tabular}{|c|c|}
\hline Variable & Description \\
\hline Growth rate $(\mathrm{g})$ & Real GDP growth rate \\
\hline Expenditure & Total general government expenditure, mill.EUR /GDP, mill.EUR \\
\hline $\begin{array}{l}\text { Non- } \\
\text { Distortionary }\end{array}$ & Taxes on production and imports mill.EUR /GDP, mill.EUR \\
\hline Distortionary & $\begin{array}{l}\text { Current taxes on income, wealth; Net social contributions; Capital } \\
\text { taxes mill.EUR / GDP, mill.EUR }\end{array}$ \\
\hline General & $\begin{array}{l}\text { General public services, mill.EUR / Total general government } \\
\text { expenditure, mill.EUR }\end{array}$ \\
\hline Defence & Defence, mill.EUR / Total general government expenditure, mill.EUR \\
\hline Order & $\begin{array}{l}\text { Public order and safety, mill.EUR / Total general government } \\
\text { expenditure, mill.EUR }\end{array}$ \\
\hline Affairs & $\begin{array}{l}\text { Economic Affairs, mill.EUR / Total general government expenditure, } \\
\text { mill.EUR }\end{array}$ \\
\hline Environment & $\begin{array}{l}\text { Environment protection, mill.EUR / Total general government } \\
\text { expenditure, mill.EUR }\end{array}$ \\
\hline $\begin{array}{l}\text { Housing } \\
\text { Health }\end{array}$ & \\
\hline Health & Health, mill.EUR / Total general government expenditure, mill.EUR \\
\hline Recreation & $\begin{array}{l}\text { Recreation, culture and religion, mill.EUR / I otal general government } \\
\text { expenditure, mill.EUR }\end{array}$ \\
\hline Education & Education, mill.EUR / Total general government expenditure, mill.EUR \\
\hline Social & $\begin{array}{l}\text { Social protection, mill.EUR / Total general government expenditure, } \\
\text { mill.EUR }\end{array}$ \\
\hline Deficit & Deficit; surplus/GDP, mill.EUR \\
\hline $\begin{array}{l}\text { Employment } \\
\text { growth }\end{array}$ & Employment growth, annual average \\
\hline Population growth & Population growth rate, annual average \\
\hline Investment ratio & Households investment to GDP ratio \\
\hline GDP per capita & GDP per capita, Purchasing power parities (EU28=1) \\
\hline Inflation & HICP $(2005=100)$, Annual average rate of change \\
\hline
\end{tabular}




\section{References}

ACOSTA-ORMAECHEA, S. and A. MOROZUMI. 2013. Can a Government Enhance Long-run Growth by Changing the Composition of Public Expenditure?, IMF Working Paper , No. 13/162

AFONSO, A. and D. FURCERI. 2008. Government size, composition, volatility and economic growth. ECB Working Paper (No. 849): pp.1-45

AFONSO, A. and J. T. JALLES. 2013. Fiscal Composition and Long-term Growth. BALLING, Morten and Axel A WEBER. States, banks, and the financing of the economy: fiscal policy and sovereign risk perspectives. ISBN 9783902109675. ISSN 978-3-902109-67-5.

AGÉNOR, P. R. 2006. A Theory of Infrastructure-led Development. In: Centre for Growth and Business Cycle Research Discussion Paper Series. The University of Manchester.

BAFFES, J. and A. SHAH. 1998. Productivity of Public Spending, Sectoral Allocation Choices, and Economic Growth. Economic Development and Cultural Change. (No. 2) ISSN 0013-0079-984602.

BALTAGI, Badi H. 2008. Econometric analysis of panel data. 4th ed. Hoboken, NJ: John Wiley, xiii, 351 p. ISBN 978-047-0518-861.

BARRO, R. 1990. Government spending in a simple model of endogenous growth. Journal of Political Economy. (Vol.98): pp. 103-117.

BARRO, R. J. and X. SALA-I-MARTIN. 2004. Economic growth. 2nd ed. Cambridge, Mass.: MIT Press, xvi, 654 p. ISBN 02-620-2553-1.

BENOS, N. 2009. Fiscal Policy and Economic growth: Empirical Evidence from EU Countries. Munich Personal RePEc Archive paper.

BLEANEY, M., N. GEMMELL and R. KNELLER. 2001. Testing the Endogenous Growth Model: Public Expenditure, Taxation, and Growth over the Long Run. Canadian Journal of Economics. (34).

CULLISON, W. E. 1993. Public Investment and Economic Growth. Federal Reserve Bank of Richmond Economic Quarterly. (No.4)

DEVARAJAN, S., V. SWAROOP and H. ZOU. 1996. The composition of public expenditure and economic growth. Journal of Monetary Economics. (37)

DRUKKER, D. M. 2003. Testing for serial correlation in linear panel-data models. The Stata Journal (2003). (No.3).

EASTERLY, W. and S. REBELO. 1993. Fiscal Policy and Economic Growth: An Empirical Investigation. Journal of Monetary Economics. (No.3)

EUROSTAT,. 2014. European system of national and regional accounts - ESA 2010. EUROSTAT Statistics Explained .

EVANS, P. and G. KARRAS. 1994. Are Government Activities Productive? Evidence from a Panel of U.S. States. The Review of Economics and Statistic

GEMMELL, N., F. MISCH a B. MORENO-DODSON. 2012. Public Spending for Long-Run Growth: A Practitioners' View. World Bank - Economic Premise. (99)

GEMMELL, N., R. KNELLER and I. SANZ. 2009. The Composition of government expenditure and economic growth: some evidence from OECD countries. In: BARRIOS, S., L. PENCH and A. SCHAECHTER. The quality of public finances and economic growth: proceedings to the annual workshop on public finances (Brussels, 28 November 2008) . Luxembourg: Office for Official Publications of the European Communities

GEMMELL, N., R. KNELLER and I. SANZ. 2014. Does the Composition of Government Expenditure Matter for Long-run GDP Levels? Working Paper Series. Victoria University of Wellington, Chair in Public Finance, (3516)

KNELLER, R., M.F. BLEANEY and N. GEMMELL. 1999. Fiscal policy and growth: evidence from OECD countries. Journal of Public Economics. (74): pp.171-190

KUKK, K. 2007. Fiscal Policy Effects on Economic Growth: Short Run vs Long Run. Working Papers in Economics. School of Economics and Business Administration, Tallinn University of Technology. (No.167)

OECD. 2013. Government at a glance [online]. OECD Publishing. ISBN 2221-4399.

ROMERO DE ÁVILA, D. and R. STRAUCH. 2008. Public finances and long-term growth in Europe: 
Evidence from a panel data analysis. European Journal of Political Economy (No.24)

ROODMAN, D. 2009. How to Do xtabond2: An Introduction to "Difference" and "System" GMM in Stata. The Stata Journal (2009). (No. 9): pp. 86-136

SALVADORI, N. 2003. The theory of economic growth: a 'classical' perspective. Northampton, Mass.: Edward Elgar, xiii, 395 p. ISBN 18-437-6010-X.

SEMmLER, W., A. GREINER, B. DIALLO, A. REZAI and A. RAJARAM. 2007. Fiscal Policy, Public Expenditure Composition, and Growth: Theory and Empirics. The World Bank Policy Research Working Papers. (4405) 